\title{
MATOS, Maria Izilda Santos de; AVELINO, Yvone Dias (org.). Deslocamentos: desafios, territórios e tensões (passado e presente nas Tecituras das Cidades). São Paulo: e-Manuscritos: PIPEq, 2018. 247 p.
}

\author{
Arthur Daltin Carrega* \\ *Pesquisador independente - Assis, SP, Brasil \\ arthurdcar@outlook.com \\ https://orcid.org/0000-0002-8366-9134
}


Movimentos migratórios recentemente estabelecidos seguidos pela instauração de novas ordens socioeconômicas, bem como processos de inclusão - ou não - de estrangeiros no conjunto da sociedade, têm suscitado a curiosidade de historiadores e outros cientistas sociais. O livro Deslocamentos: desafios, territórios e tensões (passado e presente nas Tecituras das Cidades), organizado por Maria Izilda Santos de Matos e Yvone Dias Avelino, figura, nesse cenário, como uma contribuição relevante, pois coleta dez reflexões de diferentes autores atentos a teorias e métodos atualizados, e as relaciona com o tema em questão mobilizando debates, levantando hipóteses e ampliando horizontes de pesquisas da área das humanidades.

Os textos têm recortes e fontes diversificados, sugerindo a pesquisadores a importância de um olhar mais completo no trabalho de interpretação dos vestígios humanos ligados às transmigrações, com o objetivo comum, entretanto, de compreender os contextos sociais, políticos, econômicos e culturais que os viajantes deixaram para trás e aqueles que encontraram na nova morada.

O texto de abertura, assinado por Henrique Rodrigues, apresenta indagações que reivindicam adaptações metodológicas nos exames dos movimentos migratórios. Segundo o autor as pesquisas desconsideram o perfil dos expatriados que chegaram ao Brasil e lidam com perigos de formar conclusões arbitrárias e imprecisas, por isso, defende que essas ponderações atentem para fontes mais plenas, das quais destaca os livros de registros de passaportes portugueses.

Paulo César Gonçalves escreve o segundo ensaio com o objetivo de contextualizar os conceitos de "emigrante/imigrante" e "colono" em documentos legislativos portugueses e brasileiros entre os séculos XVI e XIX; realizando uma análise de longa duração que considera distintos ambientes políticos, econômicos e sociais, ele argumenta que é muito difícil delimitar os termos historicamente, uma vez que não existe colonização sem imigração e a independência política de 1822 não desencadeou embaraços para esse fluxo de almas, que continuou atendendo interesses de pessoas buscando "melhores condições de vida em terras ligadas por laços muito antigos" (p. 61); porém, as especificidades existem e marcam rupturas e continuidades em momentos históricos determinados.

O terceiro capítulo coube a Celeste Castro, que se debruçou sobre os passaportes emitidos pelo Estado português entre o final do século XIX e o início do XX, e atenta para os interesses do governo lusitano no controle das 
emigrações que, segundo a historiadora, configuram uma tentativa de garantir o domínio sobre essas expatriações, utilizando pretextos burocráticos e financeiros, dada a obrigatoriedade da emissão do passaporte para todos que pretendiam deixar Portugal.

Lená Menezes pensou no sentido de desmistificar a ideia de que as relações entre imigrantes portugueses no Brasil no início do século XX eram absolutamente harmônicas. Para ela, apesar dos laços vernáculos, a história da comunidade lusitana na capital nacional da Primeira República é repleta de conflitos. Havia entre esses "irmãos de terra" a exploração violenta do trabalho, incluindo parentes, enriquecimento de uns em detrimento de outros, inúmeros casos de violência por diversos motivos e rompimentos de relações amorosas. A autora propõe que historiadores que estudam o assunto considerem essas intensas disputas e desavenças, somando contribuições mais plenas à historiografia.

Yvone Adelino desenvolve um trabalho em cima da documentação referente à Confeitaria Colombo, em funcionamento no Rio de Janeiro desde $1894 \mathrm{e}$ tombada como patrimônio cultural da cidade em 1982. Ela propõe uma análise que mira identificar os gostos e costumes da elite fluminense através da investigação da documentação oferecida pelo estabelecimento, que se consagrou como um exemplo do requinte e do luxo da Belle Époque Tropical. Segundo a historiadora, a instalação disponibilizava um ambiente - expresso nos doces e na arquitetura - baseado em novidades do mercado europeu, que atraiu imigrantes saudosos de sua terra natal.

No sexto artigo Maria Izilda Matos apresenta uma pesquisa que estudou a vida intelectual de dois escritores portugueses, Maria Archer (1899-1982) e Barradas de Carvalho (1920-1980), que viveram exilados ao Brasil durante a ditadura de Antônio de Oliveira Salazar (1932-1968). Moradores da capital paulista, os dois imigrantes se destacaram pela participação na redação do periódico Portugal Democrático e pela oposição ao regime salazarista em vigor do outro lado do Atlântico; nesse sentido, ambos tem uma trajetória que interessa à cientistas da história das ideias, em especial as de resistência ao fascismo e ao regime político imposto pelo chefe de Estado luso.

Sênia Bastos, no sétimo ensaio, publicou um estudo desenvolvido em cima da legislação brasileira entre 1947 e 1951. Seu objetivo foi compreender o fluxo do grupo conhecido como "deslocados de guerra", especialmente aqueles oriundos da Alemanha e Áustria. Segundo ela, a pretexto do "melhoramento da raça”, 
o governo brasileiro selecionou esses estrangeiros classificando-os em "aceitáveis" ou "inaceitáveis" a partir de um filtro que considerava a utilidade econômica e a tradição deles, procurando formas de barrar a entrada de judeus e comunistas.

O trabalho de Maura Véras expõe um diagnóstico sociológico sobre as condições de vida de latino-americanos vivendo atualmente na cidade de São Paulo. Ela busca compreender as razões que levaram esses imigrantes a procurar abrigo na capital paulista e qual situação encontraram. Véras informa que esses estrangeiros se estabelecem em uma situação precária e com intensas dificuldades sociais, que envolvem: moradia insalubre, exploração extrema, perseguições xenofóbicas, privação de direitos, baixos salários, entre outras mazelas. O estudo coaduna, ainda, pesquisas que buscam identificar as contribuições culturais e sociais dessas pessoas na composição do município e não esconde seu posicionamento favorável na luta pela inclusão definitiva delas na comunidade local.

Lúcia Maria Bógus e Suzana Pasternak seguem a mesma linha e publicam um estudo sobre a região metropolitana paulista. Os retirantes analisados pelas cientistas, porém, são oriundos de outras regiões do Brasil e do próprio estado de São Paulo. Elas empreendem um exame estatístico exaustivo dessa movimentação de pessoas, identificando oito diferentes categorias sócio-ocupacionais, que estão em dispersão pelas 38 cidades do território. $\mathrm{O}$ artigo se conclui em forma de tópicos, apresentando informações que indicam a manutenção da tendência observada nos últimos anos.

O último artigo compete a Dulce Maria Baptista, que relaciona o debate dos movimentos migratórios às redes sociais, entendidas como "unidades fundamentais de vida social" (p. 240). Segundo ela essas redes são formadas e organizadas por imigrantes para garantir a si e a seus iguais a sobrevivência, além de oferecer contatos com aspectos culturais de seu país de origem. A razão para essa medida seria a ineficiência do Estado e dos órgãos internacionais, que não conseguem criar condições que atendam as necessidades desses forasteiros.

Conclui-se assim que o livro comporta um interessante valor científico, já que incita debates relacionados à questão dos deslocamentos humanos. Os textos publicados retomam discussões historiográficas conhecidas e expõem novidades em abordagens e métodos, que podem ser exportados e apurados em outras conjunturas políticas, econômicas, sociais e culturais, intrigando 
leitores a desenvolver outros pontos de partida para pesquisas relacionadas aos deslocamentos humanos.

A coletânea sugere ainda que a compreensão do atual cenário global é fundamental para a formulação das perguntas que orientarão essas investigações, cujas conclusões podem contemplar pontos palpitantes da contemporaneidade. O trabalho a ser realizado, assim, apesar de interpretar documentos e fatos históricos, deve considerar a leitura das conjunturas hodiernamente estabelecidas, ofício que cabe e é função do historiador (Hobsbawm, 2013, p. 24).

\section{Referência}

HOBSBAWM, E. Sobre história (ensaios). Tradução: Cid Knipel Moreira. São Paulo: Companhia das Letras, 2013. 